International Research Journal of Engineering, IT \& Scientific Research
Available online at https://sloap.org/journals/index.php/irjeis/
Vol. 5 No. 4, July 2019, pages: 68 74
ISSN: 2454-2261
https://doi.org/10.21744/irjeis.v5n4.717

\title{
Dyslexia: Ways to Identify and Address It
}

\author{
Johanna Margarita Catagua Vasquez ${ }^{\text {a }}$ \\ Pamela Mariana Zambrano Quiroz ${ }^{\text {b }}$ \\ Maria Elena Moya Martinez ${ }^{\mathrm{c}}$
}

Article history:

Received: 18 March 2019

Accepted: 31 May 2019

Published: 31 July 2019

\section{Keywords:}

dyslexia;

learning difficulty;

learning;

rhythms;

styles;

\begin{abstract}
Dyslexia is a reading and write-related learning disorder that affects many children, who are mostly untreated and treated to reduce the problems this represents and not become a barrier to those who have it because they are not aged Did it on time. The analysis through the bibliographic review of various authors, is the method used to make a study of the incidence of dyslexia, through this it is considered to review the styles and rhythms of learning since different problems arise from this such as aspect analyzed, it is also known what causes children to present these characteristics, what the consequences are and how the teacher can detect in order to use different measures. Several conclusions are obtained by being the most relevant that teachers have to have knowledge and preparation to be able to care for children with this difficulty. The goal itself is to know and know different contexts where children with dyslexia problems have been analyzed, to know other aspects that allow eradicating this that affects not only the performance of students but also the unfolding of many Teacher. The study was made by relating different contributions of authors and was carried out at the School of Basic Education Angel Arteaga Cañarte of the Canton Santa Ana, during the 2019-2020 school year, to analyze the number of students with this difficulty and power deal with the different cases.
\end{abstract}

2454-2261 ${ }^{\circledR}$ Copyright 2019. The Author. This is an open-access article under the CC BY-SA license (https://creativecommons.org/licenses/by-sa/4.0/) All rights reserved.

\section{Author correspondence:}

Vasquez,

Master's student of the Pontificia Universidad Católica del Ecuador, sede Manabí, Portoviejo.

Email address: johanna.catagua@educacion.gob.ec

\section{Introduction}

In the classroom there will always be problems in terms of the learning process, this is because not all students have the same learning model or because they have a learning disorder that does not allow them to have a good academic advancement, among these is dyslexia which is a problem that has nothing to do with intelligence but

${ }^{a}$ Pontificia Universidad Católica del Ecuador, Portoviejo, Ecuador

${ }^{\mathrm{b}}$ Pontificia Universidad Católica del Ecuador, Portoviejo, Ecuador

${ }^{\mathrm{c}}$ Pontificia Unifersidad Católica del Ecuador, Portoviejo, Ecuador 
rather with other forms or rhythms of learning that are based on difficulty writing, therefore they also have problems in reading and interpretation (Delgado et al., 2019; Martinez et al., 2019).

This type of disorder should be detected in time by the teacher who must attend and seek possible solutions to achieve changes in learning and by unwrapping students with these characteristics; Students who are immersed in this difficulty are usually those who exhibit bad behavior or who are very quiet in-class hours. This is where the teacher must play a leading role because, in his hands, there will be the responsibility of being able to help that student so that his disorder does not reach a point where he loses self-esteem when discriminated against. Time and lack of knowledge would be a point against the teacher but it should not be an excuse, because every teacher must be in constant preparation to be attentive to these kinds of problems and be able to provide timely help to the child.

There are studies where the prevalence of dyslexia has been shown in various contexts and it has been concluded that this disorder affects approximately $80 \%$ of subjects with learning difficulties (Velez et al., 2016).

In addition, it is considered globally based on a study made approximately in 2016 by the National Institute of Neurological Disorder and Stroke established that it exists between 5\% and 15\% of students possess this difficulty, considering dyslexia as one learning disorders most often in education (De la Peña, 2016; Menéndez \& Martinez, 2019).

There is also a study made in the city of Cuenca, 207 students between 8 and 13 years old, both from public and private institutions, $26.57 \%$ of students of whom 365 has superficial, 33\% phonological and $31 \%$ mixed dyslexia (Vélez et al., 2015).

The objective of this research is to make an analysis based on the contribution of several authors, on the incidence of dyslexia and to look for the causes, consequences, ways of detecting and addressing it; to raise awareness and know that dyslexia is a problem that students present and is often not detected by teachers.

\section{Materials and Methods}

The methodology used in the research is the bibliographic allaying, modality of academic work, through which the analysis of the contribution of each author is used allowing to make a better focus on the realization of this work, for this purpose research was investigated articles and thesis related to the subject and the most relevant and related aspects of the subject were obtained from them

\section{Results and Discussions}

\subsection{Learning styles and rhythms}

Talking about this topic is extremely important to begin to understand why for many teachers it becomes a chaos or a problem within the classroom with certain students who have a different way of learning from each other, is that when you talk about style in the educational field, refers to the form or model that each student uses for the assimilation of content in the teaching-learning process and when talking about rhythm refers to the speed or slowness of receiving all this knowledge, and it is precisely this subject that clearly shows that many times teachers are not aware of this and want to teach all students equally without respecting any of these aspects, by teaching equally what you get is that students who have an e different rhythm and rhythm do not assimilate and have poor academic performance; this will be discussed in this work a problem already known to teachers such as dyslexia.

\subsection{What is a dyslexic child?}

A dyslexic child is one who although he presents a normal intelligence is not able to read, interpret and write just like children of the same educational level and even if he is being motivated and receives the attention of the teacher it is often not enough to correct these kinds of problems, when the teacher does not have the necessary tools to do so.

The dyslexic child presents a learning difficulty of neurological origin, characterized by difficulties of fluidity and precision in trying to recognize written words and when reading, caused by a deficit in the phonologic component, unexpected, taking note that a child's cognitive abilities have normal development (Carrillo, 2012).

Vasquez, J. M. C., Quiroz, P. M. Z., \& Martinez, M. E. M. (2019). Dyslexia: ways to identify and address it. International Research Journal of Engineering, IT \& Scientific Research, 5(4), 68-74. 


\subsection{Types of dyslexia}

Usually two types of dyslexia are identified that are phonological dyslexia which is the one that shows difficulty in the conversion of grapheme-phoneme and by it the student uses the lexical route, while superficial dyslexia uses the phonological route which is characteristics of students who cannot recognize the word as a whole, that is to say when receiving words do it guided by sound and not by spelling (Tamayo, 2017a).

\subsection{Causes of dyslexia}

There are studies explaining that there are various causes but it must be considered that not all who have this problem have the same symptoms, for this it is indicated that there are neuro-cognitive hypotheses that try to find the explanation to this problem and based on studies done highlight that it is the product deficit related to brain abnormalities. In addition it is considered that this problem occurs in the first instance in the relationship between reading and phonology, in second instance it is established that it may be a cause of visual deficit or subtle visoatencional which indicates that the student has a disorder in what is Reading, finally, there's another conclusion that explains or considers dyslexia as a memory learning disorder (Pernet et al., 2011). We cannot rule out that it could also be caused by problems at birth, the existence of a family member who has trouble speaking, or because the child has had difficulty learning to speak his or her first words.

The following table shows some aspects that may be considered and that are related to the above:

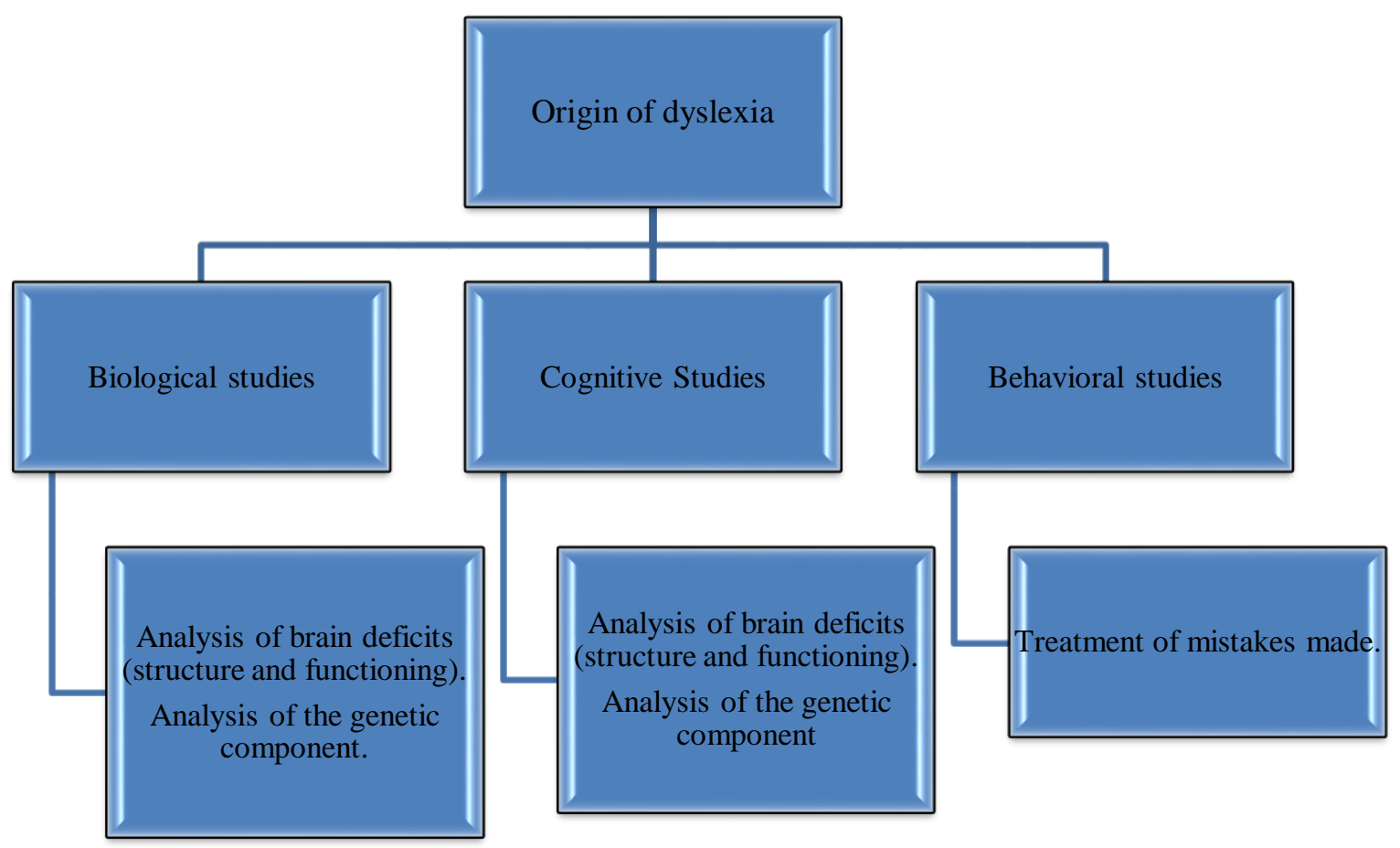

Figure 1. Origin of dyslexia

Source: (Tamayo, 2017b)

\subsection{How to spot a dyslexic child}

Among the features presented by a child with dyslexia problems can be named the following: Errors at the time of reading or writing, confusion of letters, syllables or words, repetition of letters, problems of reading comprehension, among others, which causes the student to gradually decrease their concentration and understanding of the tasks to be performed by always trying to decipher the work to be done. Others are known that dyslexics over twelve years old have no difficulty in reading, but if it is easy to detect them in silent reading, that is, when reading 
and presenting lip movement and are forced to pronounce the words in a voice to be able to understand and this is because when reading in mute they apply the technique of oral reading and this they do it very slowly.

There are other aspects such as when they try to remember past events, words or sounds, do not visually memorize objects, words or letters, have difficulty learning series, among others (Mendez, 2003).

\subsection{Tackling Dyslexia}

When the teacher suspects that a child is dyslexic it is important to perform various exercises to help him, the important thing is to perform the following exercises before the age of 8 or 9 , because this is the best time to intervene on time and prepare the child, because the child advancing in grades will only make this problem more visible.

\section{Phonological Awareness Exercises}

The aim of this type of exercise is to improve the ability to represent and operate with the sounds of language, to exercise memory.

\section{Syllabic Awareness Exercises}

Ask the student to tell us how many syllables a word has

That he tries to omit a certain syllabus, to replace one syllable with another, Ask for the hidden syllabus to indicate, Identify the repeated syllable, Sort syllables to form words or complete words.

\section{Phonemic Awareness Exercises}

Have the student say how many sounds a certain word has to Skip a sound, to replace a certain sound from one word to another; Ask you to indicate the hidden phoneme or missing sound in any word.

Repeating syllables or words; Give you images, objects and so on so that those that carry the sound surround.

\section{Lexical Awareness Exercises}

a) Mentally counting words, that is, to tell how many different words there are in prayer

b) Ask him to omit a word from the prayer so that he is aware of what is going on.

c) Replace one word with another in prayer

d) Write sentences with certain words. Etc.

e) Compensatory spelling exercises, letter soups, and rhymes

f) In addition to making dictations of sounds, words can also be made games for the student to declare, or perform activities with rhymes.

Orientation exercises and visual discrimination of symbols and graphemes

Allow the child to find and surround the ones the teacher names by writing multiple syllables or letters. It helps the student find the grapheme, syllable or word equal to the model (Silva, 2011).

\subsection{Consequences}
a) Low school performance
b) Low self-esteem
c) Disinterest in studying
d) Rejection or frustration when instructed to read or write
e) Colleagues who often show rejection
f) They adopt another identity in order to be included in some group
g) Think they're not smart (Villa, 2015).

Dyslexia has nothing to do with students' mental ability, but with a set of disorders presented in literacy, where mental activities make it difficult to differentiate letters, and when writing can present several errors and confusion, for this reason the teacher will be the only one who can detect this problem through school activities (Guerrero, 2016).

Vasquez, J. M. C., Quiroz, P. M. Z., \& Martinez, M. E. M. (2019). Dyslexia: ways to identify and address it. International Research Journal of Engineering, IT \& Scientific Research, 5(4), 68-74. 


\section{Conclusion}

Dyslexia does not occur superficially, this is a consequence of the development of skills and notions, since directionality, visual perception, sequencing, the viso-spatial notion, are presented from the initial level, making that when the student I'm in the first year of basic education and the years that follow, what it will do is that the problem has increased. A dyslexic student can be the product of a child who has people in his household with speech problems, the pressure to learn to read in a certain time, by the demand of having excellent academic performance, among others.

\section{Conflict of interest statement}

The authors declared that they have no competing interest.

\section{Statement of authorship}

The authors have a responsibility for the conception and design of the study. The authors have approved the final article.

\section{Acknowledgments}

The authors would like to thank the editor of IRJEIS for their valuable time, support, and advice in completing the current research. 


\section{References}

Carillo, M. (2012). La dislexia: bases teóricas para una práctica eficiente. Ciencias Psicológicas, VI (2), $185-194$. Obtenido de http://www.redalyc.org/comocitar.oa?id=459545417007

De-La-Peña, C. \& Bernabéu, E. (2018). Dislexia y discalculia: una revisión sistemática actual desde la neurogenética. Universitas Psychologica, 17(3), 1-11. Obtenido de https://doi.org/10.11144/Javeriana.upsy173.ddrs

Delgado, M. A. C., Delgado, R. I. Z., Palma, R. P., \& Moya, M. E. (2019). Dyscalculia and pedagogical intervention. International Research Journal of Management, IT and Social Sciences, 6(5), 95-100. https://doi.org/10.21744/irjmis.v6n5.710

Guerrero, G. (2016). Dificultades de la dislexia en el proceso de la lecto-escritura en los niños del tercer año de Educación General Básica de la Escuela Particular Carlos Crespi II. (Tesis Pregrado). Universidad Politécnica Salesiana, Cuenca. Obtenido de https://dspace.ups.edu.ec/bitstream/123456789/12385/1/UPS-CT006464.pdf

Martinez, C. J. B., Vasquez, B. S. G., Martinez, M. E. M., \& Gámez, M. R. (2019). Learning problems on educational context for cascol parish. International Journal of Social Sciences and Humanities, 3(2), 145-155. https://doi.org/10.29332/ijssh.v3n2.306

Méndez, R. (2003). Investigación y planificación para el diseño de un aula de apoyo psicopedagógico y aporte de la misma al desarrolo y seguridad de la educacion de niños con dificultades de aprendizaje, 3(2), 1-118. Obtenido de http://repositorio.iaen.edu.ec/bitstream/24000/243/1/IAEN-021-2003.pdf

Menéndez, E. S., \& Martinez, M. E. M. (2019). Problems of learning and pedagogical intervention. International Journal of Social Sciences and Humanities, 3(2), 105-111. https://doi.org/10.29332/ijssh.v3n2.301

Pernet, C., \& Dufor, O., \& Démonet, J. (2011). Redefiniendo la dislexia: explicando la variabilidad. Escritos de Psicología - $\quad$ Psychological Writings, $4 \quad$ (2), 17-24. file://C:/Users/USER/Downloads/artículo_redalyc_271022095003.pdf

Silva, C. (2011). ¿Cómo ayudar a mi hijo disléxico?. La dislexianet. Obtenido de http://www.ladislexia.net/comoayudar-a-mi-hijo-dislexico/

Tamayo Lorenzo, S. (2017). La dislexia y las dificultades en la adquisición de la lectoescritura. Profesorado. Revista de Currículum y Formación de Profesorado, 21 (1), 423-432.

Tamayo, P., Slonim, D., Mesirov, J., Zhu, Q., Kitareewan, S., Dmitrovsky, E., ... \& Golub, T. R. (1999). Interpreting patterns of gene expression with self-organizing maps: methods and application to hematopoietic differentiation. Proceedings of the National Academy of Sciences, 96(6), 2907-2912.

Vélez Calvo, X., Tárraga Mínguez, R., Fernández Andrés, M., Sanz-Cervera, P., Blázquez-Garcés, J., \& Tijeras Iborra, A. (2016). Incidencia de la dislexia en ecuador: relación con el ci, lateralidad, sexo y tipo de escuela. International Journal of Developmental and Educational Psychology. Revista INFAD de Psicología., 2(1), 249258. Obtenido de http://dx.doi.org/10.17060/ijodaep.2015.n1.v2.64

Vélez, X., Tárraga, R., \& Fernández, M., \& Sanz, P., \& Blázquez, J., \& Tijeras, A. (2015). Incidencia de la dislexia en ecuador: relación con el ci, lateralidad, sexo y tipo de escuela. International Journal of Developmental and Educational Psychology, 2 (1), 249-257. Obtenido de http://www.redalyc.org/resumen.oa?id=349851784023

Villa, W. (2015). Dificultad del aprendizaje - Dislexia que se realizará en la Escuela República de Chile en el Séptimo Año de Educación General Básica. (Tesis Pregrado). Universidad Politécnica Salesiana, Cuenca. Obtenida de https://dspace.ups.edu.ec/bitstream/123456789/12349/1/UPS-CT006448.pdf

Vasquez, J. M. C., Quiroz, P. M. Z., \& Martinez, M. E. M. (2019). Dyslexia: ways to identify and address it. International Research Journal of Engineering, IT \& Scientific Research, 5(4), 68-74. 


\section{Biography of Authors}

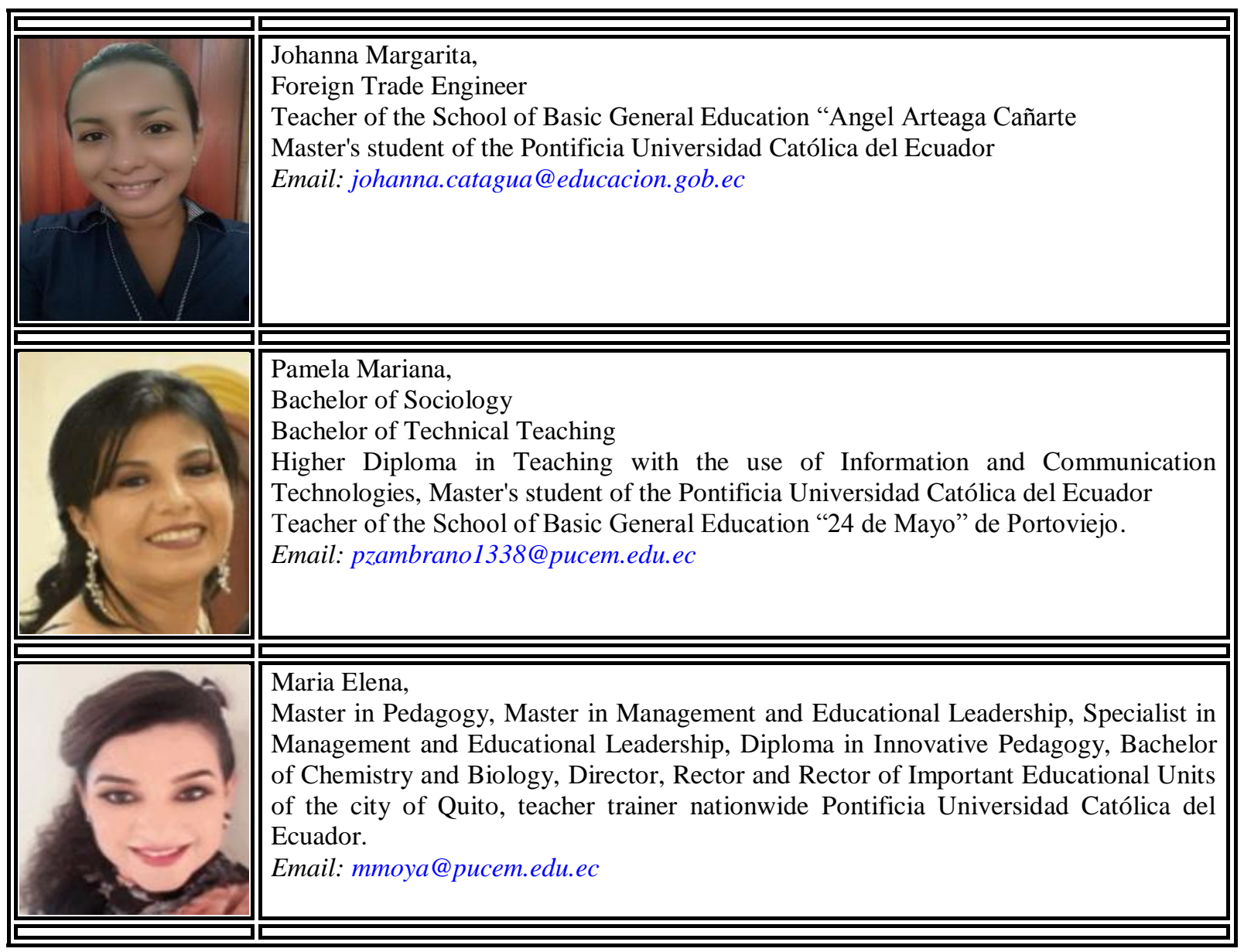

